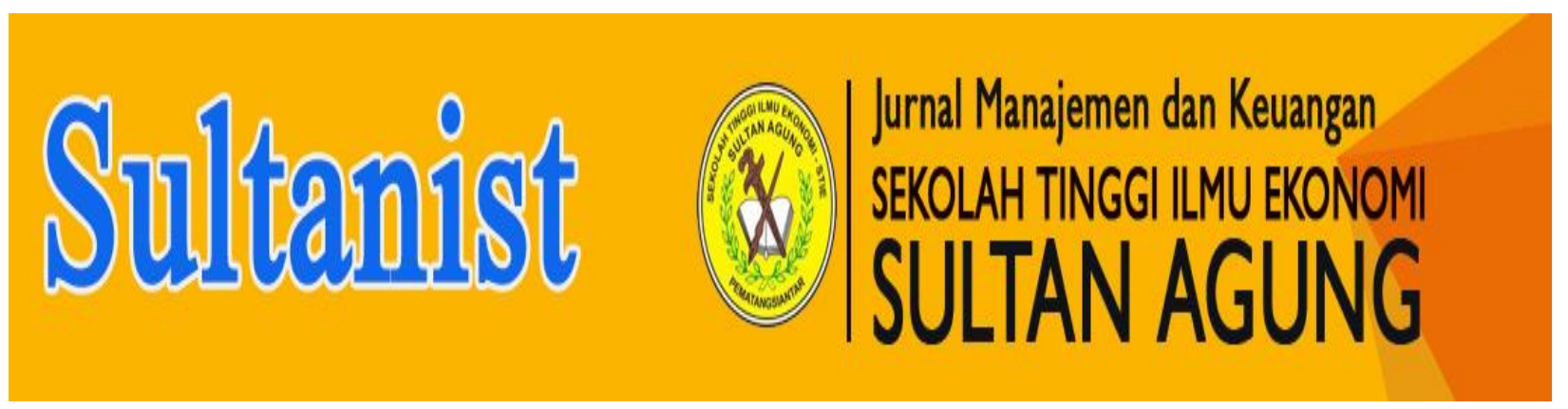

\title{
PENGARUH DISIPLIN KERJA DAN GAYA KEPEMIMPINAN TERHADAP KINERJA KARYAWAN PADA PT CAPELLA MEDAN CABANG PEMATANGSIANTAR
}

\author{
Oleh : \\ Ahmad Kurniawan \\ S1 Manajemen \\ Darwin Lie, Efendi, Kartini Harahap
}

\begin{abstract}
Abstrak
Hasil penelitian ini dapat disimpulkan sebagai berikut: 1. Karyawan menyatakan disiplin kerja baik, gaya kepemimpinan dan kinerja karyawan dikategorikan baik. 2. Hasil analisis regresi $\hat{\mathrm{Y}}=19,070+0,280 \mathrm{X}_{1}+0,447 \mathrm{X}_{2}$, artinya terdapat pengaruh yang positif antara disiplin kerja dan gaya kepemimpinan terhadap kinerja karyawan 3. Hasil analisis korelasi diperoleh nilai $r=0,787$, artinya terdapat hubungan yang kuat dan positif antara variabel disiplin kerja dan gaya kepemimpinan dengan kinerja karyawan. Baik tidaknya kinerja karyawan dapat dijelaskan koefesien determinasi oleh disiplin kerja serta gaya kepemimpinan dapat sebesar 61,9\%. 4. Hipotesis $\mathrm{H}_{0}$ ditolak, artinya disiplin kerja dan gaya kepemimpinan berpengaruh positif dan signifikan terhadap kinerja karyawan pada PT Capella Medan Cabang Pematangsiantar.

Adapun saran dari penelitian ini adalah untuk meningkatkan pengaruh disiplin kerja, maka perusahaan harus meningkatkan sanksi tegas terhadap karyawan yang melanggar dengan peraturan disiplin kerja yang telah diterapkan perusahaan. Untuk mewujudkan gaya kepemimpinan yang efektif dan seimbang, hendaknya pimpinan harus mampu membuat keputusan sendiri, dan mampu menggunakan Gaya kepemimpinan yang baik sesuai dengan wewenang sebagai pimpinan. Untuk meningkatkan kinerja karyawan yaitu dengan memberikan himbauan dan pelatihan terhadap karyawan agar terciptanya kemampuan bekerjasama antar pimpinan, rekan kerja dapat berjalan lebih optimal.
\end{abstract}

Kata Kunci: Disiplin Kerja, Gaya Kepemimpinan dan Kinerja Karyawan

\section{ABSTRACT}

The results of this study can be summarized as follows: 1. Employees declare good work discipline, leadership style and employee performance is categorized well. 2. Regression analysis result $\hat{Y}=19,070+0,280 X 1$ $+0,447 X 2$, meaning there is positive influence between work discipline (X1) and leadership style (X2) on employee performance $(Y)$. 3. Correlation analysis results obtained $r$ value $=0,787$, meaning there is moderately and positive correlation between work discipline variables and leadership style with employee performance. Whether or not the performance of employees can be explained coefficient of determination by work discipline and leadership style can be 61,9\%. 4. HO Hypothesis rejected, meaning that work discipline and leadership style have a positive and significant impact on employee performance at PT Capella Medan Branch Pematangsiantar.

As for suggestion of this research is to increase the influence of work discipline, hence company have to increase sanction firmly to employees who violate with work discipline regulation which have been applied company. To realize an effective and balanced leadership style, leaders should be able to make their own decisions, and be able to use a good leadership style in accordance with authority as a leader. To improve employee performance that is by giving appeal and training to employees to create the ability to cooperate between leaders, co-workers can run more optimally.

Keywords: Work Discipline, Leadership Style and Employee Performance

\section{A. PENDAhuluan}

\section{Latar Belakang Masalah}

PT Capella Medan Cabang Pematangsiantar bergerak dalam bidang perdagangan kendaraan (Dealer) merek Daihatsu pertama di Sumatera Utara. PT Capella Medan Cabang Pematangsiantar berusaha agar selalu dipercayai sebagai supplier kendaraan merek Daihatsu ke perusahaan-perusahaan besar yang ada di wilayah Sumatera Bagian Utara dengan dilengkapi bengkel sehingga memudahkan para pengguna mobil merek Daihatsu melakukan service kendaraannya. Oleh karena itu PT Capella Medan Cabang Pematangsiantar membutuhkan kinerja karyawan yang bermanfaat sehingga menjadi penentu keberhasilan suatu perusahaan melalui program visimisi yang ada didalam perusahaan.

Salah satu faktor yang mempengaruhi kinerja karyawan adalah disiplin kerja. Disiplin kerja sangat menentukan sikap dan perilaku yang menjadi sebuah kebiasaan sehari-hari karyawan di dalam melakukan pekerjaan. karyawan yang sering masuk kerja tidak tepat waktu dan terlambat masuk setelah jam istirahat dan ada beberapa peraturan dan prosedur yang berkaitan dengan jam kerja sering dilanggar oleh karyawan, kemampuan untuk menyelesaikan pekerjaan dengan baik dan bekerja sesuai dengan jabatan karyawan, sangat menghormati sikap dan perilaku pimpinan perusahaan, menerapkan sanksi dan ketegasan dengan baik untuk diberikan kepada 
karyawan jika melanggar peraturan, sikap adil yang baik terhadap semua karyawan yang bekerja di dalam satu perusahaan, menciptakan suasana lingkungan kerja yang nyaman bagi karyawan yang akan bekerja, memberikan balas jasa terhadap karyawan yang berprestasi.

Selain disiplin kerja, faktor yang mempengaruhi kinerja karyawan adalah gaya kepemimpinan. Dalam upanya meningkatkan kinerja karyawan, PT Capella Medan Cabang Pematangsiantar menerapkan gaya kepemimpinan otokratis, gaya kepemimpinan demokratis. gaya kepemimpinan demokratis yang lebih mendominasi dibandingkan dengan gaya kepemimpinan yang lain karena sering melibatkan karyawan dalam pengambilan keputusan serta mau menghargai ide karyawan lain.

\section{Rumusan Masalah}

a. Bagaimana gambaran disiplin kerja, gaya kepemimpinan dan kinerja karyawan pada PT Capella Medan Cabang Pematangsiantar.

b. Bagaimana pengaruh disiplin kerja dan gaya kepemimpinan terhadap kinerja karyawan pada PT Capella Medan Cabang Pematangsiantar.

\section{Tujuan Penelitian}

a. Untuk mengetahui gambaran disiplin kerja, gaya kepemimpinan dan kinerja karyawan pada PT Capella Medan Cabang Pematangsiantar.

b. Untuk mengetahui pengaruh disiplin kerja dan gaya kepemimpinan terhadap kinerja karyawan pada PT Capella Medan Cabang Pematangsiantar baik secara simultan maupun parsial.

\section{Metode Penelitian}

objek penelitian dalam hal ini adalah PT Capella Medan Cabang Pematangiantar yang terletak di Jalan Medan KM 6 Simp. Karangsari Pematangsiantar. Telepon (0622) 23765; Faksimile: (0622) 435365. Populasi adalah sekuruh karyawan PT Capella Medan Cabang Pematangsiantar yang berjumlah 30 orang akan menjadi sampel sebagai responden untuk menjawab kuesioner yang disebarkan. Hal ini disebut juga dengan sampel jenuh. Adapun desain penelitian yang digunakan dalam penulisan skripsi ini adalah penelitian kepustakaan (library research) dan penelitian lapangan (Field Research). Teknik pengumpulan data yang dipergunakan dalam penelitian ini adalah metode kuisioner, metode wawancara dan metode dokumentasi. Jenis data yang adalah jenis data kualitatif dan data kuantitatif. Hasil data yang diperoleh dari lapangan akan dianalisis secara deskriptif baik bersifat kualitatif dan kuantitatif.

\section{B. LANDASAN TEORI}

\section{Manajemen dan Manajemen Sumber Daya Manusia}

Menurut Daft (2002:8), manajemen merupakan cara yang efektif efisien untuk meraih pencapain sasaran sasaran organisasi melalui perencanaan, pengorganisasian, dan pengendalian sumber daya manusia organisasi. Menurut Dessler (2006:5), manajemen sumber daya manusia adalah proses memperoleh, melatih, menilai dan memberikan kompensasi kepada karyawan, memperhatikan hubungan kerja mereka, kesehatan dan keamanan, serta masalah keadilan. Menurut Mondy (2008:4), fungsi manajemen sumber daya manusia adalah :

1) Pengembangan sumber daya manusia, adalah fungsi utama yang tidak hanya terdiri dari pelatihan dan pengembangan namun juga aktivitas perencanaan dan pengembangan karir individu, pengembangan organisasi serta manajemen dan penilaian kinerja. Pelatihan dirancang untuk memberi para pembelajar sejumlah pengetahuan dan keterampilan yang diperlukan untuk pekerjaan mereka saat ini.

2) Penyediaan staf, adalah suatu proses yang menjamin suatu organisasi selalu memiliki jumlah karyawan yang tepat dan keahlian yang memadai dalam pekerjaan yang tepat. Penyediaan staf mancakup analisis pekerjaan, perencanaan sumber daya manusia, perekrutan, dan seleksi.

3) Keselamatan dan kesehatan, keselamatan adalah perlindungan bagi karyawan dari luka yang disebabkan kecelakaan yang terkait dengan pekerjaan. Kesehatan adalah bebasnya para karyawan dari sakit secara fisik atau emosi.

4) Kompensasi, kompensasi adalah mencakup semua imbalan total yang diberikan kepada karyawan sebagai timbal balik atau jasa mereka. Kompensasi tersebut dapat dibagi menjadi kompensasi finansial langsung atau tidak langsung.

\section{Disiplin Kerja}

Menurut Rivai (2011:825), disiplin kerja merupakan suatu cara mengubah perilaku dan sebagai upaya untuk meningkatkan kesadaran dan kesediaan seseorang dalam memenuhi segala peraturan perusahaan yang dipergunakan para manajer dalam berkomunikasi dengan para karyawannya. Menurut Handoko (2000:208), mengemukakan bahwa disiplin adalah kegiatan manajemen untuk menjalankan standar-standar organisasi.

Menurut Saydam (2005:291), indikatorindikator disiplin kerja adalah sebagai berikut:

1) Frekuensi kehadiran

Frekuensi kehadiran adalah tingkat kehadiran karyawan setiap harinya didalam perusahaan. Frekuensi kehadiran dapat diartikan pula dimana karyawan selalu datang dan pulang tepat pada waktunya.

2) Tujuan dan kemampuan

Tujuan (pekerjaan) yang akan dicapai harus realitas dan ditetapkan dengan jelas, serta dapat mengembangkan kreativitas karyawan. Dengan kata lain, tujuan (pekerjaan) yang diberikan kepada karyawan harus sesuai dengan kemampuan karyawan tersebut, sehingga karyawan akan melakukan pekerjaan tersebut dengan sungguh-sungguh. 
3) Keteladanan pemimpin

Pemimpin dapat menjadi faktor yang menentukan kedisiplinan karyawannya, karena seorang pemimpin biasanya dijadikan teladan dan panutan oleh para karyawannya. Pemimpin harus menjadi contoh yang baik kepada karyawannya, seperti berperilaku jujur, adil, serta berdisiplin. Pimpinan jangan mengharapkan para karyawannya berdisiplin jika pimpinan itu sendiri kurang berdisiplin. Pemimpin harus menyadari bahwa perilaku dan perbuatannya akan dicontoh dan diteladani oleh para karyawannya. Oleh karena itu seorang pimpinan harus mempunyai perilaku serta berdisiplinan yang baik, dengan harapan akan dicontoh dan diikuti oleh para karyawannya.

4) Sanksi dan ketegasan

Sanksi adalah salah satu cara yang dilakukan dalam memelihara kedisiplinan karyawan. Dengan adanya sanksi, karyawan akan mempertimbangkan segala perilaku yang akan diperbuatnya. Sanksi harus ditetapkan berdasarkan pertimbangan lofis, masuk akal, dan diinformasikan secara jelas kepada semua karyawan, bersifat mendidik, dan menjadi suatu alat untuk memelihara kedisiplinan dalam perusahaan. Ketegasan pimpinan dalam melakukan tindakan akan mempengaruhi kedisiplinan karyawannya. Pimpinan harus tegas dalam melakukan tindakan serta harus berani untuk menghukum setiap karyawannya yang berperilaku indisipliner akan disegani dan diakui kepemimpinannya oleh karyawannya, sehingga pimpinan akan dapat memelihara kedisiplinan karyawannya.

5) Keadilan

Para dasarnya dalam setiap manusia terdapat ego yang merasa dirinya penting dan ingin diperlakukan sama dengan manusia yang lainnya. Atas dasar tersebut maka seorang pimpinan harus bersikap adil kepada para karyawannya. Balas jasa ataupun sanksi yang diberikan akan meransang terciptanya kedisiplinan karyawan yang baik apabila didasari dengan keadilan. Dengan keadilan yang baik akan menciptakan kedisiplinan yang baik pula.

6) Hubungan kemanusiaan

Hubungan kemanusiaan yang harmonis diantara sesama karyawan ikut menunjang dalam menciptakan kedisiplinan yang baik dan suasana kerja yang nyaman pada suatu perusahaan. Hubungan-hubungan tersebut dapat bersifat vertikal maupun horizontal. Pemimpin harus berusaha menciptakan suasana hubungan kemanusiaan yang serasi serta mengikat, vertikal maupun horizontal diantara sesama rekan kerja. Hal ini akan memotivasi kedisiplinan yang baik dalam perusahaan.

7) Balas jasa

Balas jasa berperan serta dalam mempengaruhi kedisiplinan karyawan karena balas jasa akan

SULTANIST: Jurnal Manajemen dan Keuangan memberikan kepuasan dan kecintaan karyawan terhadap perusahaan/pekerjaanya. Untuk mewujudkan kedisiplinan karyawan yang baik, perusahaan harus mampu memberi balas jasa yang sesuai kepada karyawannya. Kedisiplinan karyawan tidak mungkin baik apabila jasa yang mereka terima kurang memuaskan untuk memenuhi kebutuhan hidupnya.

\section{Gaya Kepemimpinan}

Menurut Luthans (2009:680), gaya kepemimpinan adalah gaya yang digunakan oleh manajer atau penyelia pada manajemen sumber daya manusia. menurut Prasetyo (2008:17), gaya kepemimpinan merupakan bentuk perilaku yang dapat dibuat mengintegrasikan tujuan dengan tujuan individu.

menurut Handoko (2004:155), ada tiga macam gaya kepemimpinan yaitu:

1) Gaya Otokratis

Ciri -ciri gaya kepemimpinan

a) Semua penentuan kebijaksanaan dilakukan pemimpin

b) Teknik-teknik dan langkah-langkah kegiatan didikte atasan setiap waktu sehingga langkah-langkah yang akan datang selalu tidak pasti untuk tingkat luas

c) Pemimpin biasanya mendikte tugas kerja bersama setiap anggota Penerapan gaya kepemimpinan otokratis hanya dapat digunakan saat menghadapi keadaan darurat.

2) Gaya Demokratis

Ciri-ciri gaya kepemimpinan demokratis yaitu:

a) Semua kebijaksanaan terjadi pada kelompok diskusi dan keputusan diambil dengan dorongan dan bantuan dari pemimpin

b) Kegiatan-kegiatan didiskusikan, langkahlangkah umum untuk tujuan kelompok dibuat dan bila dibutuhkan pemimpin menyarankan beberapa alternative prosedur yang dipilih.

c) Para anggota bebas bekerja dengan siapa yang mereka pilih dan pembagian tugas dilakukan kelompok. Penerapan gaya kepemimpinan demokratis memberikan keuntungan berupa keputusan dan tindakan yang diambil oleh objektif, timbul rasa ikut memiliki serta terbina moral yang tinggi. Kelemahan dari gaya kepemimpinan ini adalah keputusan yang diambil lambat dan kurang adanya ketegasan karena kurang campur tangan dari pimpinan sehingga kadang-kadang keputusan yang dibuat bukan keputusan terbaik.

3) Gaya Bebas Kendali (Laissez-Faire)

Ciri-ciri gaya kepemimpinan bebas kendali (Laissez-Faire) yaitu:

a) Kebebasan penuh bagi keputusan kelompok atau individu

b) Tidak adanya partisipasi dari pemimpin dalam penentuan tugas (pemimpin tidak mengambil bagian dalam diskusi kerja) 


\section{Kinerja Karyawan}

Menurut Rivai (2005:14), mengemukakan kata kinerja jika dilihat dari asal katanya adalah terjemahan dari kata performance yang berasal dari kata to perform yang artinya melaksanakan atau menyempurnakan tanggung jawab. Kinerja adalah hasil atau tingkah keberhasilan seseorang secara keseluruhan selama periode tertentu didalam melaksanakan tugas dibandingkan dengan berbagai kemungkinan seperti standart hasil kerja, target atau sasaran atau kriteria yang telah ditentukan terlebih dahulu dan disepakati bersama. menurut Zainal (2009:447), kinerja merupakan suatu istilah secara umum yang digunakan untuk sebagian atau seluruh tindakan atau aktivitas dari suatu organisasi pada suatu periode dengan referensi pada sejumlah standart seperti biaya-biaya masa lalu atau yang diproyeksikan, dengan dasar efisiensi, pertanggungjawaban atau akuntabilitas manajemen dan semacamnya.

Menurut Mathis dan John (2006:378), ada lima elemen-elemen yang mempengaruhi kinerja karyawan:

1) Kuantitas dari hasil, kuantitas dari hasil dapat diartikan sebagai hasil dari jumlah pekerjaan yang dihasilkan oleh karyawan. Kuantitas dapat diukur dengan rupiah, unit, dan lain-lain.

2) Kualitas dari hasil, kualitas dari hasil dapat diartikan sebagai kesempurnaan hasil pekerjaan yang dihasilkan oleh karyawan.

3) Ketepatan waktu dari hasil, ketepatan disini dapat diartikan sebagai kesesuaian penyelesaian pekerja karyawan dengan tenggang waktu yang disediakan.

4) Kehadiran, ketepatan dari para karyawan untuk hadir ditempat kerja sesuai atau lebih awal dari waktu yang ditentukan.

5) Kemampuan bekerja sama, kesediaan dari karyawan untuk bekerja sama dalam satu tim dalam menyelesaikan pekerjaan.

\section{Pengaruh Disiplin Kerja Gaya Kepemimpinan terhadap Kinerja Karyawan.}

Menurut Sutrisno (2011:98), disiplin yang baik mencerminkan besarnya tanggung jawab seseorang terhadap tugas-tugas yang diberikan kepadanya. Melalui disiplin akan mencerminkan kekuatan karena biasanya seseorang yang berhasil dalam karyanya adalah mereka yang memiliki disiplin tinggi. Disiplin yang baik dari karyawan akan menunjukkan bahwa suatu perusahaan dapat memelihara dan menjaga loyalitas maupun kualitas karyawannya. Selain itu, dengan mengetahui disiplin kerja karyawan maka nilai kinerja dari para karyawan pun akan dapat diketahui. Gaya kepemimpinan yang efektif dan efisien dapat meningkatkan kinerja karyawan untuk mengukur besar kecilnya perjalanan suatu perusahaan untuk mencapai tujuan yang diinginkan. bahwa adanya tingkat kinerja karyawan yang baik dengan ditopang disiplin kerja dan gaya kepemimpinan yang dilaksanakan secara efektif dan

SULTANIST: Jurnal Manajemen dan Keuangan efesien sehingga dapat menimbulkan berjalannya suatu perusahaan dengan baik.

\section{PEMBAHASAN}

\section{Analisis}

\section{a. Deskriptif Kualitatif}

Analisa deskriptif dimaksudkan untuk mendapatkan gambaran atau deskripsi mengenai tanggapan dari karyawan mengenai pengaruh disiplin kerja dan gaya kepemimpinan terhadap kinerja karyawan pada PT Capella Medan Cabang Pematangsiantar. Setelah pengujian data maka langkah selanjutnya melakukan pengkajian kualitatif sebagai gambaran fenomena dari variabel penelitian pada saat sekarang ini. Adapun penetapan kriteria nilai rata-rata jawaban dari responden tersebut dimasukkan kedalam kelas-kelas interval dimana penentuan intervalnya memakai rumus sebagai berikut:

Interval Kelas $=$ Nilai Tertinggi - Nilai Terendah

$$
\begin{aligned}
& =\frac{5-1}{5} \\
& =\frac{4}{5} \\
& =0,8
\end{aligned}
$$

Dari rumus diatas dapat diperoleh interval kelas 0,8 sehingga berlaku ketentuan kategori dengan hasil berikut:

Tabel 1

Nilai Interval dan Kategori Jawaban Responden.

\begin{tabular}{|c|c|c|c|}
\hline \multirow{2}{*}{$\begin{array}{c}\text { Nilai } \\
\text { Interval }\end{array}$} & \multicolumn{3}{|c|}{ Kategori } \\
\cline { 2 - 4 } & $\begin{array}{c}\text { Disiplin } \\
\text { Kerja }\end{array}$ & $\begin{array}{c}\text { Gaya } \\
\text { Kepemimp } \\
\text { inan }\end{array}$ & $\begin{array}{c}\text { Kinerja } \\
\text { Karyawa } \\
\text { n }\end{array}$ \\
\hline $1,00-1,80$ & $\begin{array}{c}\text { Sangat } \\
\text { Tidak } \\
\text { Baik }\end{array}$ & $\begin{array}{c}\text { Sangat } \\
\text { Tidak Baik }\end{array}$ & $\begin{array}{c}\text { Sangat } \\
\text { Tidak } \\
\text { Baik }\end{array}$ \\
\hline $1,81-2,60$ & $\begin{array}{c}\text { Tidak } \\
\text { Baik }\end{array}$ & Tidak Baik & $\begin{array}{c}\text { Tidak } \\
\text { Baik }\end{array}$ \\
\hline $2,61-3,40$ & $\begin{array}{c}\text { Cukup } \\
\text { Baik }\end{array}$ & $\begin{array}{c}\text { Cukup } \\
\text { Baik }\end{array}$ & $\begin{array}{c}\text { Cukup } \\
\text { Baik }\end{array}$ \\
\hline $3,41-4,20$ & Baik & Baik & Baik \\
\hline $4,21-5,00$ & $\begin{array}{c}\text { Sangat } \\
\text { Baik }\end{array}$ & $\begin{array}{c}\text { Sangat } \\
\text { Baik }\end{array}$ & $\begin{array}{c}\text { Sangat } \\
\text { Baik }\end{array}$ \\
\hline
\end{tabular}

Sumber: hasil pengelolahan data

\section{1) Gambaran Disiplin kerja pada PT Capella Medan Cabang Pematangsiantar}

Dari hasil analisa, dapat diketahui bahwa jawaban atas dimensi frekuensi kehadiran dengan indikator ketepatan waktu masuk kerja karyawan diperoleh nilai rata-rata 4,10 dengan kategori jawaban baik, karena ketapatan waktu masuk kerja karyawan sangat memperdulikan proses berjalannya suatu perusahaan dengan baik. Pada indikator ketepatan pulang kerja karyawan diperoleh nilai rata-rata 4,16 dengan kategori jawaban baik, karena perusahaan menerapkan disiplin yang kuat sehingga karyawan harus mematuhinya. Pada indikator tingkat kehadiran karyawan setiap hari diperoleh nilai rata-rata 3,86 
dengan kategori jawaban baik, karena perusahaan mengutamakan tingkat kehadiran karyawan setiap harinya didalam perusahaan.

Dimensi tujuan dan kemampuan dengan indikator pekerjaan yang diberikan sesuai dengan keahlian diperoleh nilai rata-rata 3,26 dengan kategori jawaban cukup baik, karena setiap karyawan belum mampu menyelesaikan pekerjaan berdasarkan keahliannya dengan baik, agar lebih ditingkatkan kinerja karyawan untuk memperoleh pekerjaan yang baik. Pada indikator pekerjaan yang diberikan sesuai dengan pekerjaan sehari-hari diperoleh dengan nilai rata-rata 3,23 dengan kategori jawaban cukup baik, karena karyawan belum mampu mengerjakan pekerjaan dengan cukup baik yang dikerjakan setiap hari, agar lebih ditingkatkan lagi untuk memperoleh yang lebih optimal. Pada indikator melaksanakan tugas sesuai jabatan diperoleh dengan nilai rata-rata 4,10 dengan kategori jawaban baik, karena karyawan mampu menyelesaikan pekerjaan yang sesuai dengan jabatannya.

Pada dimensi keteladanan dengan indikator pimpinan memberikan ketegasan dalam disiplin kerja karyawan diperoleh nilai rata-rata 4,16 dengan kategori jawaban baik, karena pimpinan mampu menerapkan ketegasan disiplin karyawan dalam bekerja. Pada indikator pimpinan memberikan perilaku yang baik terhadap karyawan diperoleh dengan nilai rata-rata 3,86 dengan kategori jawaban baik, karena pimpinan dapat memberikan sikap dan perilaku yang baik oleh setiap karyawan lainnya. Pada indikator pimpinan mengingatkan karyawan disiplin itu penting diperoleh dengan nilai rata-rata 3,56 dengan kategori jawaban baik, karena pimpinan selalu mengingatkan kepada karyawan agar berdisiplin disaat bekerja.

Pada dimensi sanksi dan ketegasan dengan indikator ketegasan pimpinan untuk memberikan sanksi terhadap karyawan yang tidak disiplin diperoleh dengan nilai rata-rata 3,16 dengan kategori jawaban cukup baik, karena karyawan yang tidak disiplin perusahaan masih belum tegas untuk memberikan sanksi. Pada indikator sanksi hukuman karyawan jika melanggar peraturan diperoleh dengan nilai rata-rata 3,53 dengan kategori jawaban baik, karena pimpinan mampu memberikan hukuman yang sebanding kepada karyawan yang melanggar peraturan disiplin. Pada indikator sanksi yang diberikan karyawan sesuai dengan pelanggaran yang dilakukan diperoleh dengan nilai rata-rata 3,80 dengan kategori jawaban baik, karena pemimpin dapat adil memberikan sanksi terhadap karyawan yang melanggar peraturan disiplin sesuai dengan karyawan perbuat.

Pada dimensi keadilan dengan indikator pimpinan memberikan sikap adil kepada karyawan yang mendapat sanksi diperoleh dengan nilai rata-rata 3,86 dengan kategori jawaban baik, karena pimpinan selalu memberikan sikap adil berupa sanksi kepada karyawan yang tidak disiplin. Pada indikator pimpinan memberikan sikap adil terhadap semua karayawan diperoleh dengan nilai rata-rata 3,66 dengan kategori jawaban baik, karena pimpinan

SULTANIST: Jurnal Manajemen dan Keuangan selalu bersikap adil kepada karyawan bawahan. Pada indikator ketegasan pimpinan untuk menerapkan sikap adil agar terciptanya kenyamanan karyawan diperoleh dengan nilai rata-rata 3,86 dengan kategori jawaban baik, karena pimpinan tidak menerapkan sistem pilih kasih terhadap karyawan.

Pada dimensi hubungan kemanusiaan dengan indikator sikap menghargai masukan yang positif karyawan diperoleh dengan nilai rata-rata 3,46 dengan kategori jawaban baik, karena pimpinan selalu menghargai masukan yang positif pada semua karyawan. Pada indikator sikap menghormati antara pimpinan dan bawahan diperoleh dengan nilai ratarata 3,60 dengan kategori jawaban baik, karena pimpinan selalu menghormati hasil pekerjaan yang dibuat karyawan maupun sebaliknya. Pada indikator sikap menghargai antar karyawan satu dengan karyawan lainnya diperoleh dengan nilai rata-rata 3,56 dengan kategori jawaban baik, karena setiap karyawan selalu menghargai pekerjaan terhadap karyawan lain.

Pada dimensi balas jasa dengan indikator kesesuaian imbalan jasa yang diberikan karyawan yang baik diperoleh dengan nilai rata-rata 3,80 dengan kategori jawaban baik, karena perusahaan dapat memberikan balas jasa yang sesuai yang diharapkan karyawan yang baik. Pada indikator kesesuaian gaji yang diterima terhadap karyawan yang sudah lama bekerja diperoleh dengan nilai ratarata 3,86 dengan kategori jawaban baik, karena balas jasa yang diterima karyawan seimbang dengan pekerjaan yang dilakukan. Pada indikator kesesuaian perusahaan untuk memberikan imbalan jasa terhadap karyawan yang disiplin diperoleh dengan nilai ratarata 3,66 dengan kategori jawaban baik, karena imbalan yang diberikan karyawan yang disiplin sesuai yang diharapkan karyawan.

Dari seluruh uraian di atas dapat disimpulkan bahwa faktor-faktor Disiplin Kerja baik dinilai dengan rata-rata 3,72, hal ini dinilai dengan hal yang positif terhadap pekerjaan dalam melaksanakan tugas dan kewajibannya. Pada tabel tersebut diperoleh dengan nilai rata-rata tertinggi yaitu terdapat ada indikator ketepatan pulang kerja karyawan yaitu 4,16 dan indikator memberikan ketegasan pimpinan dalam disiplin kerja karyawan yaitu 4,16, sedangkan pada nilai terendah pada indikator ketegasan pimpinan memberikan sanksi terhadap karyawan yang melanggar peraturan yaitu 3,16 .

\section{2) Gambaran Gaya Kepemimpinan pada PT Capella Medan Cabang Pematangsiantar}

Dari hasil analisa, dapat diketahui bahwa jawaban atas dimensi gaya kepemimpinan otokratis pada indikator ketepatan anggapan pimpinan atas keputusannya diperoleh nilai rata-rata 3,73 dengan kategori jawaban baik, karena pimpinan tepat untuk membuat keputusannya. Pada indikator ketepatan anggapan pimpinan keputusan dari orang lain tidak tepat diperoleh nilai rata-rata 3,36 dengan kategori jawaban cukup baik, karena pimpinan tidak mau mendengar dari keputusan orang lain. Pada indikator anggapan pimpinan tidak menghargai keputusan 
karyawan lain diperoleh nilai rata-rata 4,06 dengan kategori jawaban baik, karena pimpinan selalu membuat keputusannya sudah tepat.

Pada dimensi gaya demokratis dengan indikator pimpinan membuat keputusan berdasarkan hasil diskusi diperoleh nilai rata-rata 3,83 dengan kategori jawaban baik, karena pimpinan selalu membuat keputusannya berdasarkan hasil diskusi. Pada indikator pimpinan membuat kebijakan melalui diskusi kelompok diperoleh nilai rata-rata 3,73 dengan kategori jawaban baik, karena pimpinan selalu membut keptusannya melalui diskusi kelompok. Pada indikator kebebasan anggotanya untuk bekerja diperoleh nilai rata-rata 3,63 dengan kategori jawaban baik, karena pimpinan selalu memberikan kebebasan penuh untuk karyawan yang bekerja.

Pada dimensi gaya kepemimpinan bebas kendali dengan indikator pimpinan memberikan kebebasan karyawannya untuk bekerja diperoleh nilai rata-rata 3,23 dengan kategori jawaban cukup baik, karena pimpinan tidak mau karyawan bekerja tidak pada jabatannya. Pada indikator pimpinan berhak mengambil bagian dalam diskusi diperoleh nilai ratarata 4,13 dengan kategori jawaban baik, karena pimpinan selalu berhak mengambil bagian dalam rapat. Pada indikator pimpinan ada menentukan tugas bagi karyawan diperoleh dengan nilai rata rata 3,96 dengan kategori jawaban baik, karena pimpinan selalu menentukan tugas untuk diberikan kepada karyawan.

Dari seluruh uraian di atas dapat disimpulkan bahwa gaya kepemimpinan yang dinilai dari gaya kepemimpinan otokratis, demokratis, dan bebas kendali dapat dilihat nilai rata-rata keseluruhan yang diperoleh sebesar 3,74 dengan nilai rata-rata tertinggi yaitu terdapat pada indikator pimpinan berhak mengambil bagian dalam diskusi sebesar 4,13, dan nilai terendah yaitu terdapat pada indikator pimpinan memberikan kebebasan bagi karyawannya untuk bekerja sebesar 3,23.

\section{3) Gambaran Kinerja Karyawan pada PT} Capella Medan Cabang Pematangsiantar

Dari hasil analisa, dapat diketahui bahwa indikator kuantitas kerja dimana kemampuan karyawan dalam mencapai target yang ditentukan perusahaan diperoleh nilai rata-rata 4,03 dengan kategori jawaban baik, karena kemampuan mencapai target kerja yang dilakukan karyawan dengan baik. Pada kemampuan karyawan dalam menyelesaikan pekerjaan diperoleh nilai rata-rata 3,93 dengan kategori jawaban baik, karena karyawan dapat menyelesaikan pekerjaan dengan baik. Pada persaingan karyawan dalam mencapai target diperoleh nilai rata-rata 3,23 dengan kategori jawaban cukup baik, karena para karyawan masih belum optimal untuk bersaing dalam mencapai target.

Pada indikator kualitas kerja mengenai kerapian karyawan dalam menyelesaikan pekerjaan diperoleh nilai rata-rata 3,86 dengan kategori jawaban baik, karena karyawan mampu menyelesaikan pekerjaannya dengan rapi. Pada ketelitian karyawan SULTANIST: Jurnal Manajemen dan Keuangan dalam menyelesaikan tugas diperoleh dengan nilai rata-rata 3,83 dengan kategori jawaban baik, karena karyawan teliti disaat bekerja dan setelah bekeja. Pada kualitas kerja karyawan miliki diperoleh nilai rata-rata 3,73 dengan kategori jawaban baik, karena kualitas kerja yang dimiliki karyawan sangat memuaskan bagi perusahaan.

Pada dimensi ketepatan waktu dengan indikator kemampuan karyawan dalam mematuhi ketepatan waktu masuk kerja diperoleh nilai rata-rata 3,86 dengan kategori jawaban baik, karena karyawan mampu mematuhi aturan tentang kehadiran. Pada indikator kemampuan karyawan dalam melaksanakan pekerjaan secara tepat waktu diperoleh nilai rata-rata 3,86 dengan kategoi jawaban baik, karena karyawan mampu menyelesaikan pekerjaannya dengan tepat waktu. Pada indikator kemampuan kayawan dalam menggunakan waktu secara efektif diperoleh nilai rata-rata 3,83 dengan kategori jawaban baik, karena kinerja karyawan mampu mengikuti waktu yang efektif.

Pada dimensi kehadiran dengan indikator kemampuan karyawan dalam mematuhi aturan kerja mengenai kehadiran diperoleh nilai rata-rata 3,26 dengan kategori jawaban cukup baik, karena ada beberapa karyawan yang belum mematuhui kehadiran kerja. Pada indikator kemampuan karyawan dalam memberikan surat keterangan apabila tidak hadir diperoleh nilai rata-rata 3,73 dengan kategori jawaban baik, karena karyawan masih mampu memberi kabar lewat surat apabila tidak dapat hadir bekerja. Pada indikator kehadiran karyawan untuk bekeja setiap hari diperoleh nilai rata-rata 3,76 dengan kategori jawaban baik, karena kemauan karyawan untuk hadir bekerja setiap hari.

Pada dimensi kemampuan bekerjasama dengan indikator kemampuan bekerjasama antara pimpinan dan bawahan diperoleh dengan nilai ratarata 3,70 dengan kategori jawaban baik, karena antara pimpinan dan bawahan saling bekerjasama yang baik. Pada indikator kemampuan kerjasama antara rekan kerja diperoleh nilai rata-rata 3,66 dengan kategori jawaban baik, karena sesama karyawan saling bekerjasama untuk menyelesaikan pekerjaannya. Pada indikator karyawan bekerja sama dengan customer diperoleh nilai rata-rata 3,73 dengan kategori jawaban baik, karena setiap karyawan mampu bekerja sama yang baik antar customer.

Dari seluruh uraian di atas dapat disimpulkan bahwa kinerja karyawan yang dinilai dari kuantitas, kualitas, kehadiran, ketepatan waktu, kemampuan kerjasama dapat dilihat dari nilai rata-rata 3,73 dengan rata-rata nilai tertinggi yaitu terdapat pada indikator kemampuan karyawan mencapai target yang ditentukan perusahaan yaitu sebesar 4,03 , dan nilai rata-rata terendah yaitu terdapat pada indikator persaingan karyawan dalam mencapai target yaitu sebesar 3,23.

\section{b. Deskriptif Kuantitatif}

1) Regresi Linear Berganda

Penelitian ini bertujuan untuk menganalisis pengaruh disiplin kerja dan gaya kepemimpinan 
terhadap kinerja karyawan. Analisis regresi berganda digunakan untuk mengetahui pengaruh variabel bebas (X) dan variabel terikat (Y). Analisis dilakukan dengan melakukan tabulasi jawaban responden pada kuesioner yang dijalankan. Untuk melihat pengaruh variabel dengan persamaan regresi berganda maka dilakukan perhitungan dengan menggunakan bantuan SPSS Versi 21 untuk memperoleh nilai a dan b dengan notasi sebagai berikut:

Tabel 2

Hasil Regresi Linier Berganda Coefficients $^{\mathrm{a}}$

\begin{tabular}{|c|c|c|c|c|}
\hline & \multirow{2}{*}{ Model } & \multicolumn{2}{|c|}{$\begin{array}{l}\text { Unstandardized } \\
\text { Coefficients }\end{array}$} & \multirow{2}{*}{$\begin{array}{c}\begin{array}{c}\text { Standardize } \\
\text { d } \\
\text { Coefficients }\end{array} \\
\text { Beta }\end{array}$} \\
\hline & & B & $\begin{array}{l}\text { Std. } \\
\text { Error }\end{array}$ & \\
\hline \multirow{3}{*}{1} & (Constant) & 19.070 & 5.778 & \\
\hline & Stres Kerja & .280 & .079 & .537 \\
\hline & $\begin{array}{l}\text { Konflik } \\
\text { Kerja }\end{array}$ & .447 & .204 & .332 \\
\hline
\end{tabular}

a. Dependent Variable: Kinerja.Karyawan

Sumber: data primer hasil pengolahan data SPSS Versi 21

Berdasarkan hasil pengolahan data pada tabel 2 di atas, dapat diperoleh persamaan regresi adalah sebagai berikut: $\hat{\mathrm{Y}}=19,070+0,280 \mathrm{X}_{1}+$ $0,447 \mathrm{X}_{2}$, artinya terdapat pengaruh yang positif antara disiplin kerja dan gaya kepemimpinan terhadap kinerja karyawan pada PT Capella Medan Cabang Pematangsiantar.

2) Koefisien Korelasi dan Koefisien Determinasi Hasil koefisien korelasi dan koefisien determinasi dapat dilihat pada tabel berikut:

Tabel 3

Hasil Korelasi dan Determinasi Model Summary ${ }^{b}$

\begin{tabular}{|l|c|c|r|r|}
\hline Model & $\mathbf{R}$ & $\begin{array}{c}\text { R } \\
\text { Squar } \\
\mathbf{e}\end{array}$ & $\begin{array}{c}\text { Adjusted } \\
\text { R Square }\end{array}$ & $\begin{array}{c}\text { Std. Error of } \\
\text { the Estimate }\end{array}$ \\
\hline 1 & $\mathbf{. 7 8 7}^{\mathbf{a}}$ & $\mathbf{. 6 1 9}$ & .591 & 4.122 \\
\hline
\end{tabular}

a. Predictors: (Constant), (Gaya.Kepemimpinan),

(Disiplin.kerja)

b. Dependent Variable: (kinerja.Karyawan)

Berdasarkan tabel 3 di atas, diperoleh korelasi nilai $r$ sebesar 0,787, artinya terdapat hubungan yang kuat dan positif antara variabel disiplin kerja dan gaya kepemimpinan dengan kinerja karyawan sesuai dengan kriteria koefisien korelasi pada tabel 5, kemudian diperoleh nilai koefisien determinasi yaitu 0,619 , artinya baik tidaknya kinerja karyawan dijelaskan sebesar $61,9 \%$ oleh disiplin kerja dan gaya kepemimpinan selebihnya 38,1\% dijelaskan oleh faktor lain seperti motivasi, etos kerja dan kompensasi yang tidak dibahas dalam penelitian ini.

\section{3) Uji Hipotesis}

a) Uji Simultan (Uji F)
Pengujian ini dilakukan secara simultan yaitu dilakukan untuk menentukan diterima atau ditolaknya hipotesis, pengujian hipotesis dilakukan untuk mengetahui apakah variabel disiplin kerja dan gaya kepemimpinan yang diuji berpengaruh terhadap kinerja karyawan. Jika tingkat signifikansi dibawah 0,05 maka $\mathrm{H}_{0}$ ditolak.

Untuk menghasilkan suatu kesimpulan yang valid, maka harus dilakukan uji hipotesis. Dari hasil perhitungan korelasi diketahui bahwa disiplin kerja, gaya kepemimpinan dan kinerja karyawan sangat berhubungan, untuk menguji kebenarannya maka dilakukan pengujian hipotesis dengan menggunakan program aplikasi SPSS Versi 21.

Tabel 4

Perkiraan Nilai $F_{\text {hitung }}$ ANOVA $^{b}$

\begin{tabular}{|l|r|r|r|r|r|}
\hline Model & $\begin{array}{r}\text { Sum of } \\
\text { Squares }\end{array}$ & Df & $\begin{array}{l}\text { Mean } \\
\text { Squar } \\
\text { e }\end{array}$ & F & Sig. \\
\hline $\begin{array}{l}\text { Regressio } \\
\mathrm{n}\end{array}$ & 745.092 & 2 & $\begin{array}{l}372.54 \\
6\end{array}$ & $\mathbf{2 1 . 9 2 5}$ & $\begin{array}{r}\mathbf{. 0 0 0} \\
\text { b } \\
\text { 1 Residual }\end{array}$ \\
$\begin{array}{r}458.774 \\
\text { Total }\end{array}$ & 27 & 16.992 & & \\
7 & 29 & & & \\
\hline
\end{tabular}

a. Predictors: (Constant), Gaya.Kepemimpinan, Disiplin.Kerja

b. Dependent Variable: Kinerja.Karyawan Sumber: hasil pengolahan

Berdasarkan tabel 4 di atas, diperoleh $\mathrm{F}_{\text {hitung }}$ sebesar 21,925 > $F_{\text {tabel }}$ pada tingkat $(0,05,2$ vs 27) adalah sebesar 3,35. Oleh karena $F_{\text {hitung }}>F_{\text {tabel }}$ atau taraf signifikansi $0,000<$ dari alpha 0,05, maka Ho ditolak, artinya disiplin kerja dan gaya kepemimpinan berpengaruh positif dan signifikan terhadap kinerja karyawan pada PT Capella Medan Cabang Pematangsiantar.

\section{b) Uji Parsial (Uji t)}

Pengujian ini dilakukan secara parsial yaitu dilakukan untuk menentukan diterima atau ditolaknya hipotesis, pengujian hipotesis dilakukan untuk mengetahui apakah variabel disiplin kerja dan gaya kepemimpinan yang diuji berpengaruh terhadap kinerja karyawan. Jika tingkat signifikansi dibawah 0,05 maka $\mathrm{H}_{0}$ ditolak.

Untuk menghasilkan suatu kesimpulan yang valid, maka harus dilakukan uji hipotesis. Dari hasil perhitungan koefisien korelasi diketahui bahwa disiplin kerja, gaya kepemimpinan dan kinerja karyawan sangat berhubungan, untuk menguji kebenarannya maka dilakukan pengujian hipotesis dengan menggunakan program aplikasi SPSS Versi 21.

Tabel 5

Perkiraan Nilai thitung Coefficients $^{\mathrm{a}}$

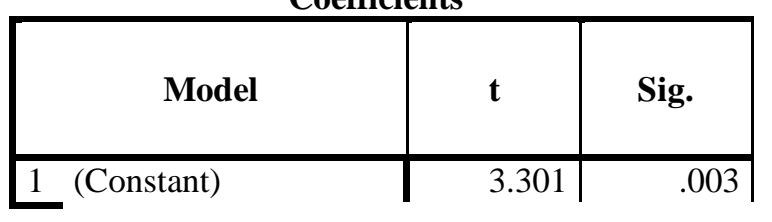

SULTANIST: Jurnal Manajemen dan Keuangan ISSN : 2338-4328 Vol. 6, No. 2, Desember 201854 


\section{D} Disiplin.Kerja

Dependent Variable: Kinerja Pegawai

Sumber: data primer hasil pengolahan kuesioner menggunakan SPSS Versi 21.

Berdasarkan tabel 5 di atas, untuk variabel (disiplin kerja) diperoleh nilai $t_{\text {hitung }}$ sebesar 3,541 > dari $t_{\text {tabel }}$ dengan $\mathrm{df}=\mathrm{n}-\mathrm{k}-1 \quad(30-2-1=27)$ sebesar 2,051 atau dengan taraf signifikan $0,001<\alpha 0,05$, maka $\mathrm{H}_{0}$ ditolak, artinya disiplin kerja berpengaruh positif dan signifikan terhadap kinerja karyawan pada PT Capella Medan Cabang Pematangsiantar. Variabel (gaya kepemimpinan) diperoleh nilai thitung sebesar 2,189 > dari tabel dengan df $=\mathrm{n}-\mathrm{k}-1$ (30-2$1=27)$ sebesar 2,051, atau dengan taraf signifikan $0,037<\alpha 0,05$, maka $\mathrm{H}_{0}$ ditolak, artinya gaya kepemimpinan berpengaruh positif dan signifikan terhadap kinerja karyawan pada PT Capella Medan Cabang Pematangsiantar.

\section{EVALUASI}

\section{a. Disiplin Kerja Karyawan pada PT Capella} Medan Cabang Pematangsiantar

Disiplin kerja pada PT Capella Medan Cabang Pematangsiantar dapat dikatakan baik, hal ini dapat dilihat dari kuesioner yang dibagikan kepada responden yang secara keseluruhan diperoleh nilai rata-rata 3,72 dengan kriteria jawaban baik.

Ada beberapa aspek yang dinilai baik tetapi masih dibawah nilai rata-rata total, pada dimensi tujuan dan kemampuan dengan indikator kesesuaian pekerjaan yang diberi pimpinan kepada karyawan berdasarkan keahlian diperoleh nilai rata-rata 3,26 dengan kriteria jawaban cukup baik, karena karyawan belum mampu menyelesaikan pekerjaan berdasarkan keahliaannya dengan baik, cara meningkatkannya pimpinan harus memberikan pekerjaan serta pelatihan kepada karyawan berdasarkan keahlian masing-masing, sehingga karyawan mampu untuk melakukan pekerjaan dengan baik. Pada indikator karyawan melaksanakan tugas sesuai dengan tugas pokok diperoleh nilai rata-rata 3,23 dengan kriteria jawaban cukup baik, karena karyawan belum mampu menyelesaikan pekerjaan dengan baik walaupun pekerjaan tersebut sesuai dengan tugas pokok yang dikerjakan setiap harinya, cara meningkatkannya perusahaan harus mampu mengembangkan kreativitas karyawan serta mampu memberikan dorongan lebih semangat kepada karyawan agar menyelesaikan tugas pokok dengan baik.

Pada dimensi keteladanan pimpinan dengan indikator pimpinan mengingatkan karyawan bahwa disiplin itu penting diperoleh nilai rata-rata 3,56 dengan kriteria jawaban baik, karena pimpinan selalu mengingatkan kepada karyawan agar disiplin disaat bekerja, cara meningkatkannya pimpinan selalu mengingatkan serta mengembangkan mengenai disiplin kerja serta mampu memberikan sanksi jika karyawan melanggar peraturan yang sudah diterapkan perusahaan yang mengenai disiplin kerja.

Pada dimensi sanksi dan ketegasan dengan indikator ketegasan pimpinan memberikan sanksi terhadap karyawan yang melanggar peraturan diperoleh nilai rata-rata 3,16 dengan kriteria jawaban cukup baik, karena karyawan yang tidak disiplin perusahaan masih belum tegas untuk memberikan sanksi, cara meningkatkannya pimpinan harus tegas dalam melakukan tindakan sanksi berupa SP (Surat Peringatan) kepada setiap karyawan yang berperilaku indisipliner sehingga pimpinan akan dapat memelihara kedisiplinan karyawan. Pada dimensi pimpinan memberikan sanksi hukuman kepada karyawan yang melanggar perarturan diperoleh nilai rata-rata 3,53 dengan kriteria jawaban baik, karena pimpinan mampu memberikan hukuman yang sebanding kepada karyawan yang tidak disiplin, cara meningkatkannya pimpinan harus mampu memberikan hukuman yang bersifat logis dan masuk akal sesuai dengan pelanggaran yang dibuat karyawan, sehingga perbuatan yang bersifat indisipliner tidak terulang kembali.

Pada dimensi keadilan dengan indikator pimpinan memberikan sikap adil terhadap karyawan yang mendapatkan sanksi diperoleh nilai rata-rata 3,66 dengan kriteria jawaban baik, karena pimpinan selalu bersikap adil kepada semua karyawan, cara meningkatkannya pimpinan mampu bersikap adil kepada para karyawan seperti memberikan balas jasa maupun sanksi sesuai dengan kriteria perusahaan, dengan keadilan yang baik akan menciptakan kedisiplinan yang optimal. Pada dimensi hubungan kemanusiaan dengan indikator sikap pimpinan selalu menghargai masukan positif terhadap karyawan diperoleh nilai rata-rata 3,46 dengan kriteria jawaban baik, karena pimpinan selalu menghargai dan mau menerima masukan maupun saran yang diberikan kepada karyawan dengan baik, cara meningkatkannya pimpinan harus selalu menghargai masukan ataupun saran terhadap karyawan bawahan untuk saling memotivasi kedisiplinan yang baik didalam karyawan. Pada indikator pimpinan menghormati karyawan bawahan diperoleh nilai rata-rata 3,60 dengan kriteria jawaban baik, karena pimpinan selalu menghormati hasil pekerjaan yang dibuat karyawan maupun sebaliknya, cara meningkatkannya pimpinan selalu menghormati karyawan bawahan serta karyawan selalu menghormati pimpinan agar hubungan kemanusiaan yang harmonis akan menunjang kedisiplinan yang baik. Pada indikator sikap karyawan menghargai karyawan satu dengan karyawan lainnya diperoleh nilai rata-rata 3,56 dengan kriteria jawaban baik, karena setiap karyawan selalu menghargai pekerjaan yang dikerjakan oleh karyawan lain, cara meningkatkannya karyawan berusaha menciptakan suasana hubungan kemanusiaan yang serasi serta mengikat, vertikal maupun horizontal diantara sesama rekan kerja. Pada dimensi balas jasa dengan indikator peraturan perusahaan yang diberikan kepada karyawan dinilai nilai rata-rata 3,66 dengan kriteria jawaban baik, karena imbalan yang diberikan kepada karyawan yang disiplin sesuai yang diharapakan karyawan, cara meningkatkannya perusahaan harus mampu memberikan balas jasa sesuai dengan peraturan 
perusahaan agar karyawan merasa puas atas pemberian jasa yang perusahaan berikan.

Disiplin kerja karyawan Pada PT Capella Medan Cabang Pematangsiantar dalam hal ini dikategorikan baik. Walaupun sudah dikategorikan baik, sebaiknya perusahaan harus meningkatkan disiplin kerja yang berupa memberikan sanksi tegas terhadap karyawan yang tidak disiplin agar menjadikan efek jera terhadap karyawan yang melanggar peraturan perusahaan.

\section{b. Gaya Kepemimpinan pada PT Capella Medan Cabang Pematangsiantar}

Gaya kepemimpinan yang diterapkan PT Capella Medan Cabang Pematangsiantar yaitu: gaya kepemimpinan otokratis, gaya kepemimpinan demokratis, dan gaya kepemimpinan laissez-faire (bebas kendali). Dari rekapitulasi jawaban responden mengenai penerapan gaya kepemimpinan PT Capella Medan Cabang Pematangsiantar berada pada nilai rata-rata 3,74 dalam kategori baik.

Ada beberapa indikator gaya kepemimpinan pada PT Capella Medan Cabang Pematangsiantar yang masih dibawah nilai rata-rata total. Pada dimensi gaya kepemimpinan otokratis dengan indikator ketepatan anggapan pimpinan atas keputusannya diperoleh nilai rata-rata 3,73 dengan kriteria jawaban baik, karena pimpinan tepat untuk membuat keputusannya, cara mengatasinya sebaiknya pimpinan harus pandai-pandai membuat keputusan agar keputusan yang dibuat bermanfaat bagi perusahaan. Pada indikator ketepatan anggapan pimpinan dari orang lain tidak tepat diperoleh nilai rata-rata 3,36 dengan kriteria jawaban cukup baik, karena pimpinan tidak mau mendengar keputusan dari orang lain, cara meningkatkannya sebaiknya pimpinan mau mendengarkan keputusan terhadap orang lain, jika keputusan orang lain sangat bermanfaat bagi perusahaan.

Pada dimensi gaya kepemimpinan demokratis dengan indikator pimpinan membuat kebijakan melalui diskusi kelompok diperoleh nilai rata-rata 3,73 dengan kategori jawaban baik, karena pimpinan selalu membuat keputusannya melalui diskusi kelompok, cara meningkatkannya pimpinan harus mampu menjalankan diskusi kelompok dengan baik agar dapat membuat keputusan yang dibuat bermanfaat bagi perusahaan. Pada indikator kebebasan anggotanya dalam bekerja diperoleh nilai rata-rata 3,63 dengan kriteria jawaban baik, karena pimpinan memberikan kebebasan penuh untuk karyawan yang bekerja, cara meningkatkannya pimpinan harus tegas untuk membuat kebebasan anggotanya bekerja sehingga nantinya karyawan tidak bermain-main untuk bekerja didalam perusahaan. Pada dimensi gaya kepemimpinan bebas kendali dengan indikator pimpinan memberikan kebebasan bagi karyawan untuk bekerja diperoleh nilai rata-rata 3,23 dengan kriteria jawaban cukup baik, karena pimpinan tidak mau karyawan bekerja tidak pada jabatannya, cara meningkatkannya sebaiknya pimpinan memiliki partisipasi yang tinggi dalam menentukan tugas dalam bekerja sesuai dengan gaya yang mereka terapkan didalam perusahaan untuk menciptakan perusahaan yang baik.

Gaya kepemimpinan pada PT Capella Medan Cabang Pematangsiantar dalam hal ini dikategorikan baik. Walaupun sudah dikategorikan baik, sebaiknya pimpinan lebih mengutamakan keputusan melalui diskusi agar mendapatkan keuntungan dan memiliki moral yang tinggi sesama karyawan dan tidak mengambil keputusan yang bersifat pribadi yaitu hanya pimpinan yang boleh mengambil keputusan didalam perusahaan.

\section{c. Kinerja Karyawan Pada PT Capella Medan Cabang Pematangsiantar}

Indikator kinerja pada PT Capella Medan

Cabang Pematangsiantar sudah dikategorikan baik. Hal ini dapat dilihat dari jawaban responden dengan nilai keseluruhan rata-rata sebesar 3,73 dengan kriteria jawaban baik.

Ada beberapa indikator kinerja karyawan yang masih dibawah nilai rata-rata total, pada dimensi kuantitas dengan indikator persaingan karyawan dalam mencapai target diperoleh nilai ratarata 3,23 dengan kriteria jawaban cukup baik, karena karyawan masih belum optimal untuk bersaing dalam mencapai target, cara meningkatkannya perusahaan harus mampu mengembangkan kuantitas kerja karyawan dengan sungguh-sungguh agar memperoleh persaingan dalam mencapai target yang baik. Pada dimensi kualitas dengan indikator kualitas kerja karyawan miliki diperoleh nilai rata-rata 3,73 dengan kriteria jawaban baik, karena kualitas kerja yang dimiliki karyawan sangat memuaskan bagi perusahaan, cara meningkatkannya perusahaan mampu memberikan pelatihan mengenai kualitas kerja karyawan sebagai kesempurnaan hasil pekerjaan yang dihasilkan oleh karyawan.

Pada dimensi kehadiran dengan indikator kemampuan karyawan dalam mematuhi aturan kerja mengenai kehadiran diperoleh nilai rata-rata 3,26 dengan kriteria jawaban cukup baik, karena ada beberapa karyawan yang belum mematuhi kehadiran kerja, cara meningkatkannya karyawan harus mampu mematuhi aturan kerja yang diterapkan perusahaan untuk dapat hadir bekerja setiap hari. Pada indikator kemampuan karyawan dalam memberikan surat keterangan apabila tidak hadir kerja diperoleh nilai rata-rata 3,73 dengan kriteria jawaban baik, karena karyawan masih mampu memberi kabar lewat surat apabila tidak dapat hadir kerja, cara meningkatkannya perusahaan harus mampu menerapkan peraturan yang tersedia diperusahaan agar dapat terciptanya kehadiran karyawan yang lebih optimal.

Pada dimensi kemampuan bekerjasama dengan indikator kemampuan bekerja sama antara pimpinan dan bawahan diperoleh nilai rata-rata 3,70 dengan kriteria jawaban baik, karena antara pimpinan dan bawahan saling bekerjasama yang baik, cara meningkatkannya perusahaan harus mampu membuat pimpinan dan bawahan selalu bekerja sama untuk memajukan perusahaan. Pada indikator kemampuan bekerja sama antararekan kerja diperoleh nilai ratarata 3,66 dengan kategori jawaban baik, karena 
sesama karyawan saling bekerja sama untuk menyelesaikan pekerjaanya, cara meningkatkannya sesama karyawan harus saling harmonis agar terciptanya suasana bekerja yang baik dan dapat menyelesaikan pekerjaan lebih optimal. Pada indikator karyawan bekerja sama dengan customernya diperoleh nilai rata-rata 3,73 dengan kriteria jawaban baik, karena setiap karyawan mampu bekerja sama yang baik dengan customer, cara meningkatkannya perusahaan harus mampu membuat karyawan bersikap sopan terhadap customernya agar customer memberikan kerja sama yang baik terhadap karyawan.

Kinerja karyawan PT Capella Medan Cabang Pematangsiantar dikategorikan baik. Walaupun dikategorikan baik, sebaiknya perusahaan harus lebih melatih maupun mengembangkan kinerja karyawan sesuai dengan keahlian masing-masing agar dapat terciptanya kinerja karyawan yang lebih optimal.

\section{KESIMPULAN DAN SARAN}

\section{Kesimpulan}

a. Hasil analisis deskriptif kualitatif tentang disiplin kerja PT Capella Medan Cabang Pematangsiantar memiliki nilai keseluruhan 3,72 dan dinilai baik. Dari rata-rata tersebut diperoleh nilai tertinggi yaitu 4,16 pada kategori ketepatan waktu pulang kerja karyawan setiap hari dan pada kategori pimpinan memberikan ketegasan dalam disiplin kerja karyawan. Nilai terendah yaitu 3,16 pada ketegasan pimpinan memberikan sanksi terhadap karyawan yang melanggar peraturan.

b. Hasil analisis deskriptif kualitatif tentang gaya kepemimpinan pada PT Capella Medan Cabang Pematangsiantar memiliki nilai keseluruhan 3,74. Dari rata-rata tersebut diperoleh nilai tertinggi yaitu 4,13 pada kategori pimpinan berhak mengambil bagian dalam diskusi, sedangkan untuk nilai terendah yaitu 3,23 pada kategori pimpinan memberikan kebebasan bagi karyawannya untuk bekerja.

c. Hasil analisis deskriptif kualitatif tentang kinerja karyawan pada PT Capella Medan Cabang Pematangsiantar memiliki nilai keseluruhan 3,73. Dari rata-rata tersebut diperoleh nilai tertinggi yaitu 4,03 pada kategori kemampuan karyawan mencapai target yang ditentukan perusahaan. Nilai terendah yaitu 3,23 pada kategori persaingan karyawan dalam mencapai target.

d. Hasil analisis regresi $\hat{Y}=19,070+0,280 \mathrm{X}_{1}+$ $0,447 \mathrm{X}_{2}$, artinya terdapat pengaruh yang positif antara disiplin kerja $\left(\mathrm{X}_{1}\right)$ dan gaya kepemimpinan $\left(\mathrm{X}_{2}\right)$ terhadap kinerja karyawan $(\mathrm{Y})$ pada $\mathrm{PT}$ Capella Medan Cabang Pematangsiantar.

e. Hasil nilai korelasi menunjukkan bahwa terdapat hubungan kuat dan positif yaitusebesar 0,787 antara variabel disiplin kerja dan gaya kepemimpinan dengan kinerja karyawan pada PT Capella Medan Cabang Pematangsiantar sesuai dengan kriteria koefisien korelasi pada tabel 5.
Kemudian diperoleh nilai koefisien determinasi yaitu 0,619 , artinya baik tidaknya kinerja karyawan dijelaskan sebesar $61,9 \%$ oleh disiplin kerja dan gaya kepemimpinan selebihnya $38,1 \%$ dijelaskan oleh faktor lain seperti motivasi, etos keja, dan kompensasi.

f. Hasil pengujian $F_{\text {hitung }}$ sebesar 21,925 $>F_{\text {tabel }}$ pada tingkat $(0,05,2$ vs 27$)$ adalah sebesar 3,35 . Oleh karena $F_{\text {hitung }}>F_{\text {tabel }}$ atau taraf signifikansi 0,000 < dari alpha 0,05, maka Ho ditolak, artinya disiplin kerja dan gaya kepemimpinan berpengaruh positif dan signifikan terhadap kinerja karyawan pada PT Capella Medan Cabang Pematangsiantar secara simultan.

g. Hasil pengujian didapat variabel disiplin kerja didapat $t_{\text {hitung }}$ sebesar 3,541 $>t_{\text {tabel }}$ sebesar 2,051 atau taraf siginifikan $0,001<$ dari alpha 0,05 maka Ho ditolak, artinya disiplin kerja berpengaruh positif dan signifikan terhadap kinerja karyawan dan gaya kepemimpinan didapat $\mathrm{t}_{\text {hitung }} 2,189>\mathrm{t}_{\text {tabel }}$ sebesar 2,051 atau taraf signifikan 0,037 < dari alpha 0,05 maka Ho ditolak, artinya gaya kepemimpinan berpengaruh positif dan signifikan terhadap kinerja karyawan pada PT Capella Medan Cabang Pematangsiantar.

\section{Saran}

a. Disiplin kerja pada PT Capella Medan Cabang Pematangsiantar sudah baik, tetapi masih terdapat beberapa indikator yang rendah. Untuk dapat meningkatkan pengaruh disiplin kerja, maka perusahaan harus meningkatkan sanksi tegas terhadap karyawan yang melanggar dengan peraturan disiplin kerja yang telah diterapkan perusahaan.

b. Gaya kepemimpinan pada PT Capella Medan Cabang Pematangsiantar sudah baik, tetapi masih terdapat beberapa indikator yang rendah. Untuk mewujudkan gaya kepemimpinan yang efektif dan seimbang pada PT Capella Medan Cabang Pematangsiantar, pimpinan harus mampu membuat keputusan sendiri, dan mampu menggunakan Gaya kepemimpinan yang baik sesuai dengan wewenang sebagai pimpinan dengan demikian para karyawan akan dapat menjalankan pekerjaannya sesuai dengan keputusan pimpinan.

c. Kinerja karyawan pada PT Capella Medan Cabang Pematangsiantar sudah baik, tetapi masih terdapat beberapa indikator yang rendah. Untuk meningkatkan dan memperbaikinya sebaiknya perusahaan memberikan himbauan dan pelatihan terhadap karyawan agar terciptanya kemampuan bekerjasama antar pimpinan, rekan kerja dapat berjalan lebih optimal.

\section{E. DAFTAR PUSTAKA}

Daft, Richard L. 2002. Manajemen. Jilid 1. Edisi Kelima. Jakarta: Erlangga

Dessler, Gary. 2006. Manajemen Sumber Daya Manusia. Jakarta: Indeks.

Handoko, T. Hani. 2000. Dasar-dasar Manajemen. Jakarta: Ghalia Indonesia. 
Handoko, T. Hani. 2004. Manajemen. Edisi Kedua. Yogyakarta: BPFE.

Luthans, Fred. 2009. Perilaku Organisasi. Yogyakarta: Penerbit Andi.

Mondy, Wayne R. 2008. Manajemen Sumber Daya Manusia. Cetakan Kedua. Bogor: Ghalia indonesia.

Mathis, Robert L. Dan John H. Jackson. 2006. Human Resource Management. Edisi X. Jakarta: Salemba Empat.

Prasetyo, Lis. 2008. Pengaruh Gaya Kepemimpinan Terhadap Kinerja. Jurnal Neo-Bisnis. Vol 2 No.2.

Rivai, Veithzel. 2005. Manajemen Sumber Daya Manusia untuk perusahaan dari teori ke praktik. Jakarta: PT Raja Grafindo Persada. 2011. Manajemen Sumber Daya Manusia untuk perusahaan dari teori ke praktik. Jakarta: PT Raja Grafindo Persada.

Saydam, Gouzali, 2005, Manajemen Sumber Daya Manusia (Human Resource) Suatu Pendekatan Mikro. Jakarta: Djanbatan.

Sutrisno, Edy. 2011. Manajemen Sumber Daya Manusia. Cetakan Ketiga. Jakarta: Kencana Prenada Media Group.

Zainal, Veithzal, et, al. 2009. Manajemen Sumber Daya Manusia untuk Perusahaan dari Teori ke Praktik. Edisi Ketiga. Jakarta: PT Raja Grafindo Persada. 